\title{
A “PANAMÉRICA TROPICALISTA” ATRAVÉS DA LITERATURA CONTRACULTURAL DE JOSÉ AGRIPPINO DE PAULA
}

\author{
Patrícia Marcondes de Barros*
}

RESUMO: O presente artigo tem o objetivo de abordar a obra Pan América (1967) do cineasta e dramaturgo José Agrippino de Paula e Silva (1937-2007), publicada no contexto da ditadura militar de 1964 e modulada pelo Movimento Tropicalista, considerado por muitos pesquisadores como a face da contracultura no Brasil. Para tratarmos do tema, apresentaremos o contexto histórico na qual a obra Pan América foi produzida e, posteriormente, analisaremos alguns de seus componentes como o insólito, o realismo fantástico e outros que propiciaram uma ruptura aos padrões literários vigentes, tanto na forma como no conteúdo, tornando-a marginal à época e alcançando o século XXI ainda como transgressora e fundadora de uma nova sensibilidade estética.

PALAVRAS-CHAVE: Contracultura; Tropicalismo; Ditadura Militar de 64; José Agrippino de Paula; Literatura brasileira.

\section{Introdução}

O presente trabalho tem como objetivo abordar a obra literária do cineasta e dramaturgo paulista José Agrippino de Paula e Silva (1937-2007), especificamente a obra Pan América (1967), produzida no período de repressão militar (1964-1985), considerada um marco da literatura contracultural no Brasil.

* Professora Adjunta da Universidade Estadual de Londrina (Uel). Pós-Doutora em Literatura, Cultura e Tradução pela Universidade Federal de Pelotas (UFPel) - PNPD-CAPES. Doutora em História e Sociedade (Identidades Culturais, Etnicidades, Migrações) pela Universidade Estadual Paulista (Unesp). 
Frente ao contexto de cerceamento da liberdade de expressão e a clandestinidade em que caíram os movimentos de oposição à ditadura em fins da década de 1960, uma parcela da juventude brasileira se envolveu com aquilo que a imprensa norte-americana denominou como contracultura ${ }^{1}$. O psicanalista e "papa do ácido lisérgico" Timothy Leary, ícone do movimento contracultural sessentista, define o termo:

[...] A contracultura é a crista movente de uma onda, uma região de incerteza em que a cultura se torna quântica. Tomando emprestada a expressão do Prêmio Nobel de Física Ilya Prigogine, a contracultura é o equivalente cultural do "terceiro estado da termodinâmica", a "região não linear" em que equilíbrio e simetria deram lugar a uma complexidade tão intensa que a nossos olhos parece caos. Aqueles que fazem parte de uma contracultura se desenvolvem nessa região de turbulências. É o seu meio natural, a única matéria maleável o bastante para ser moldada e remodelada rapidamente o bastante para dar conta da velocidade de suas visões internas. Eles conhecem a corrente, são engenheiros do caos, migrando na crista da onda da máxima mudança (LEARY APUD GOFFMAN; JOY, 2007, p. 9).

As primeiras informações sobre a contracultura no Brasil podem ser observadas no trabalho do jornalista, filósofo e artista Luiz Carlos Maciel, com a publicação da coluna Underground (1969-1971) no semanário carioca O Pasquim. Contudo, foi na década de 1970 que a contracultura foi expressa no Brasil através das manifestações artísticas de caráter experimental, chamada de produção independente. Britto (2003) expõe o ambiente e sentimento caracterizado pela "ressaca, pós-festa tropicalista" (grifo nosso), e as possíveis analogias com o underground norte-americano:

\footnotetext{
${ }^{1}$ De forma geral, entende-se historicamente como contracultura, o movimento social juvenil de caráter internacionalista relacionado às décadas de 60 e 70 que teve como mote a crítica à cultura dominante. Ganhou visibilidade e alcance no Brasil em fins da década de 60, inicialmente com o Tropicalismo e posteriormente, com a incorporação do caráter underground nas artes, na imprensa alternativa, na produção literária independente e na estética marginal, expressões de resistência frente ao momento de repressão ditatorial e de ressignificação do caráter identitário nacional. Conceitualmente e de forma perene, a contracultura floresce "sempre e onde quer que alguns membros de uma sociedade escolham estilos de vida, expressões artísticas e formas de pensamento e comportamento que incorporam o antigo axioma segundo o qual, a única verdadeira constante é a própria mudança. Sua marca é a fluidez de formas e estruturas, a perturbadora velocidade e flexibilidade com que surge, sofre mutação, se transforma em outra e desaparece" (GOFFMAN; JOY, 2007, p. 9).
} 
[...] No caso do Brasil, a contracultura começou depois — é mais um fenômeno do início dos anos setenta, do período que podemos chamar de pós-tropicalista - e veio a exibir algumas características análogas às do original californiano: as posturas em relação à política, sexualidade e drogas, as roupas e cabelos, o misticismo oriental, e também a importância do rock como linguagem musical. Porém alguns dos melhores cancionistas que utilizaram a linguagem do rock nesses primeiros anos, vários deles egressos da tropicália ou herdeiros direto dos tropicalistas, exprimiram em suas criações uma visão da realidade muito diversa da ideologia contracultural norteamericana, a qual continha, como já vimos, uma proposta utópica. No caso brasileiro, o som das guitarras serviu de pano de fundo para letras que falavam de desespero, fracasso, solidão e loucura. Nada poderia ser mais distante do "verão do amor" de 1967 que a ressaca instalada do Brasil após a alegria esfuziante do momento tropicalista (BRITTO, 2003, p. 194).

Concomitante ao desalento e a falta de liberdade de expressão advindas da ditadura militar, observava-se antagonicamente a proliferação de livros, revistas e jornais alternativos, denominados genericamente como produções contraculturais, emergentes, alternativas ou marginais que expressaram através de uma resistência estética, os novos discursos, linguagens e formas de produção, caracterizadas pelo cunho assistemático na divulgação da informação e o sentido não mercadológico (BUENO, 1979).

A obra Pan América (1967), produzida neste devir, representou uma ruptura em face das estéticas tradicionais da literatura brasileira fundindo a realidade ao insólito com um realismo fantástico, na apresentação alegórica do imaginário americano na década de 60, entrecruzando estética $p \circ p$, literatura beat, contracultura, surrealismo, entre outros horizontes descortinados na esteira do experimentalismo do Tropicalismo. Através de seus vinte capítulos, cada qual escrito em um parágrafo, narra objetivamente as mais intensas e fantásticas aventuras do autor (que é também protagonista da história) no continente americano ao lado dos mitos contemporâneos que vão desde produtores, diretores de cinema, astros da música pop a desenhos animados e personalidades políticas. A densidade, a originalidade e o espontaneísmo de sua obra semeiam a dialogia entre o político e o estético, através de uma linguagem hiperbólica que nos leva a imagens surreais e fragmentadas, indo 
do psicodelismo hippie norte-americano ao cenário das ditaduras e guerrilhas na América do Sul.

Para analisarmos o tema proposto, em um primeiro momento abordaremos o contexto histórico e significados da nascente contracultura brasileira sob a égide da ditadura militar de 1964, com algumas produções literárias contemporâneas à referida obra. Posteriormente, analisaremos a ficção, o insólito, o realismo fantástico e outros componentes que propiciaram uma ruptura aos padrões literários tanto na forma (linguagem) como no conteúdo, tornando-a marginal à época e alcançando o século XXI ainda como inovadora e fundadora de uma nova sensibilidade estética.

\section{“O caminho é pelas brechas”: O Brasil da Ditadura Militar \& a Produção Literária}

\section{Independente}

[...] A realidade continua existindo com suas brechas, e é por ela que os ousados e independentes vão enfiando suas bolas. Trabalhos atualizadíssimos (corajosos, independentes, experimentais) continuam pintando - mesmo aos poucos, mesmo na marra: a situação é de tenebras, mas a transa não morreu, nem morrerá, poetas existem (NETO, 1982, p. 145).

Segundo Hollanda (HOLLANDA APUD DIAS, 2003, p. 35): “a década de 1970 começou um pouco antes, em 1968, com a decretação do AI-5, que anunciou um período denominado pelo jornalista Zuenir Ventura de vazio cultural, caracterizado pelo silenciamento dos movimentos sociais e das artes em geral". Procurava-se, neste contexto, tentar entender o fracasso da juventude imersa na guerrilha, ou então, na loucura do "desbunde"2. "O poeta Alex Pollari em entrevista a Heloísa Buarque de Hollanda, comenta que estava

\footnotetext{
${ }^{2}$ Segundo Gonçalves (2008, p. 39), "parte dos integrantes da geração anos 1970 - o que não exclui integrantes de outras gerações -, não reconheciam mais na militância política um ideal de vida a ser seguido e, em convergência com a liberalidade proposta pelos movimentos de contracultura, adotaram o desbunde como signo de rebeldia e descrença em relação aos projetos revolucionários e, de certo modo, também à ordem vigente".
} 
na pedra do Arpoador, no Rio de Janeiro e não sabia se ia se drogar ou entrar para a guerrilha, para ele, duas opções de desespero" (DIAS, 2003, p. 35).

Alfredo Sirks comenta sobre a geração que, segundo ele, se trifurcou no Brasil:

[...] Na verdade foi uma geração, como eu gosto de dizer, que se trifurcou no Brasil. Uma parte dela, após o AI-5 quando a ditadura se transformou em ditadura total, foi para a luta armada, para a clandestinidade; outra parte resolveu ir fundo na questão da contracultura, procurando criar um universo à parte, em que fosse possível viver: foram as comunidades rurais, o uso de drogas, sobretudo das alucinógenas, como o LSD. As pessoas passaram a viver juntas em comunidades, pequenas famílias, tentando não ler jornal, sair daquela realidade, sair daquele bode, como se dizia na época. Foram as pessoas que viraram hippies. E houve um terceiro segmento daquela geração que acabou rapidamente se integrando àquilo que $o$ sistema oferecia. Porque ao mesmo tempo que vivíamos sob uma ditadura sanguinária, paradoxalmente, para a classe média intelectualizada, preparada profissionalmente, havia alternativas fantásticas de emprego e ascenção social. (SIRKIS APUD GARCIA, 1999, p. 112)

Os opositores do regime militar, em sua maioria artistas, intelectuais e estudantes, utilizavam da criatividade para realizar seu ativismo estético/político, expressos neste devir através de folhetos, jornais, revistas, manuscritos, sem padrões estéticos definidos e com distribuição precária. Segundo Luiz Carlos Maciel (1987), havia um clima de “predestinação" por parte de muitos jovens brasileiros, cujo escopo era transformar a realidade nacional, vencendo o imperialismo norte-americano em prol da justiça social e da emancipação econômica do país, o que seria alcançado através de uma revolução social e política:

[...] Tínhamos consciência que estávamos predestinados. A cultura brasileira queria se libertar definitivamente do complexo colonial e, no mínimo, igualar-se às mais desenvolvidas do planeta. No Brasil, a década começou com um grande projeto coletivo pela emancipação nacional, pelo menos no plano do espírito, e se isso não fosse de todo também possível, nos planos mais concretos, o econômico e o social. Contribuir para a execução desse projeto era responsabilidade de todo o jovem que não fosse completamente alienado. (MACIEL, 1987, p. 11) 
Nem todos os jovens foram engajados politicamente, tendo aspirações comunistas, tampouco anarquistas. No entanto, fazia-se necessário expressar seu posicionamento político, pois não o fazer, levantava postura "suspeita":

[...] Discutia-se um modelo de revolução, e como se chegar a ela. Pelo menos duas concepções se chocavam. Uma entendia a revolução como ruptura violenta, isto é, como uma explosão desencadeada por uma vanguarda que ao ser logo substituída pela classe operária, criaria uma sociedade nova e um homem novo (...). A outra posição, defendida pelo PCB, via a revolução, não como objetivo imediato, e sim como um lento processo, que poderia até culminar com uma ruptura, desde que fosse o resultado da gradual organização da sociedade civil e da acumulação de forças. Uma boa iniciação política passava pela adoção de uma ou de outra linha. (VENTURA, 1988, p. 61-62)

A crítica por parte da juventude à sociedade não se restringiu apenas a luta contra a ditadura militar, mas também ao capitalismo e a tecnocracia de forma ampla, relacionandose assim, ao movimento internacionalista dos jovens, chamado de contracultura. Theodore Roszak em sua obra $A$ Contracultura ${ }^{3}$ (1972) aponta algumas diferenças na forma como a contracultura se instituiu no mundo e seus significados sociais através do chamado conflito de gerações:

[...] Para o bem ou para o mal, a maior parte do que atualmente ocorre de novo, desafiante e atraente, na política, na educação, nas artes e nas relações sociais (amor, corte sentimental, família e comunidade) é criação dos jovens que se mostram profundamente, até mesmo fanaticamente alienados da geração de seus pais, ou de pessoas que se dirigem primordialmente aos jovens. É entre a juventude que a crítica social significativa busca hoje uma audiência receptiva, à medida que, cada vez mais, cresce o consenso de que é aos jovens que compete agir, provocar acontecimentos, correr os riscos e, de forma geral, proporcionar os estímulos. Seria interessante que o processo imemorial do conflito de gerações já tivesse deixado de ser

${ }^{3}$ A obra The Making of a counterculture de Theodore Roszak foi traduzida para o português, pela Editora Vozes em 1972, com o título A Contracultura: Reflexões sobre a sociedade tecnocrática e a oposição juvenil. Trata-se de um documento de época importante para os estudiosos da contracultura no mundo. 
uma experiência periférica na vida do indivíduo e da família e se transformado numa alavanca importante de reforma social radical. (ROSZAK, 1972, p. 15)

Foi-se desenvolvendo desde o fim da Segunda Guerra Mundial, mediante a conjuntura histórica vigente, um amplo espectro de práticas sociais e transformações que levaram à implosão de um mundo que já não correspondia aos novos paradigmas que se impunham. Marcelo Ridenti (1999) afirma que o ano de 1968 foi caracterizado por intensos protestos e mobilizações políticas em todo o mundo. Basta citar os eventos como o mitificado maio dos estudantes e trabalhadores franceses, a Primavera de Praga contra o socialismo burocrático, o massacre dos estudantes no México, as manifestações mundiais contra a Guerra do Vietnã, a alternativa da contracultura norte-americana, as guerrilhas, entre outros movimentos que adquiriram cores locais ao redor do mundo. Embora com suas especificidades, Ridenti (1999) observa alguns aspectos comuns aos movimentos libertários de 1968, como:

[...] a inserção numa conjuntura internacional de prosperidade econômica, crise no sistema escolar, ascensão da ética da revolta e da revolução, busca do alargamento dos sistemas de participação política, cada vez mais desacreditados, simpatia pelas propostas revolucionárias alternativas ao movimento soviético, recusa de guerras coloniais ou imperialistas, negação da sociedade de consumo, aproximação entre arte e política, uso de recursos de desobediência civil, ânsia de libertação pessoal das estruturas do sistema (capitalista ou comunista), mudanças comportamentais, vinculação estreita entre lutas sociais amplas e interesse imediato das pessoas, aparecimento de aspectos precursores do pacifismo, da ecologia, da antipsiquiatria, do feminismo, de movimento dos homossexuais, de minorias étnicas e outros que viriam a desenvolver-se nos anos seguintes. (RIDENTE APUD GARCIA, 1999, p. 55)

Marco Aurélio Garcia (1999) afirma que as singularidades dos movimentos contraculturais consistiam no fato de que estes buscavam novas referências para poderem refundar suas vidas através do ritmo e da postura eletrizante do rock, das experiências com as drogas e com o misticismo, do voluntarismo e da superpolitização do cotidiano. Dentro das premissas da chamada "nova consciência" (relacionada à contracultura bippie) a política 
tradicional transcende a análise marxista, ganhando outras dimensões, denunciando o aspecto desumanizador resultante do sistema tecnocrático e suas consequentes reverberações no corpo e na mente do indivíduo, independente de sua classe social. Seguindo esse raciocínio, tanto o explorado quanto o explorador do sistema capitalista padecem dos males da tecnocratização gradual da vida. Havia outros matizes de lutas não menos importantes e que transcendiam a tradicional luta de classes marxista, postulando novas indagações, linguagens de resistência e paradigmas.

A reverberação das ideias contraculturais ganhou cores específicas inicialmente com o Movimento Tropicalista, surgido em $1967^{4}$. Este movimento deflagrou uma verdadeira renovação dentro da arte brasileira, com dados e referências novas e revolucionárias, justamente num momento marcado pela repressão e obscurantismo. O Tropicalismo foi apreendido por muitos como "uma moda exótica" de viés burguês, considerado perigoso para a sociedade brasileira, devido às suas ideias libertárias, desagregadoras da família e do sistema. Foi considerado por diversos pesquisadores (BUENO, 1979; CAPELLARI, 2007; CYNTRÃO, 2000; DUNN, 2009) como a face mais expressiva do movimento hippie nos trópicos, através do processo de antropofagia cultural oswaldiana que deglutiu elementos nacionais e estrangeiros, do passado e do presente, do antigo e do moderno em suas formas e linguagens. No concernente à problemática da identidade nacional, presente em todas as produções artísticas da época, deu-se respostas desconcertantes, promovendo novas formas de ser, sentir e pensar o Brasil, assumindo "todos os pecados dos que nascem abaixo dos trópicos" (grifo do autor).

A despeito das críticas, Celso Favaretto afirma em Tropicália, alegoria, alegria (2000) que o Tropicalismo surgiu como um discurso inovador, propondo uma discussão, substancialmente distinta das anteriores, como tática cultural, proposta ideológica e relacionamento com o público.

${ }^{4}$ Segundo Contier (2003, p. 137), o Movimento Tropicalista teve duração efêmera - comumente datado com o início em setembro de 1967 e seu término, em dezembro de 1968. 
[...] O festival de música foi o ponto de partida de uma atividade que logo seria denominada de tropicalismo. A polêmica que havia cercado a apresentação das músicas transformaria Caetano e Gil em astros. A imprensa se encarregou de fazer de suas declarações desabusadas, de sua verve crítica, o prenúncio de uma posição artística, e mesmo política, sincronizada com comportamentos dos jovens de classe média, vagamente relacionado ao movimento hippie. A onda era reforçada pelo trabalho de marketing de Guilherme Araújo e aceita pelos, agora, tropicalistas. (FAVARETTO, 2000, p. 23)

Era uma posição definitivamente artística e musical, aproveitando-se das estruturas daquilo que criticavam como a própria mídia e a cultura de massa, a simplificação política elaborada pelo senso comum da classe média, a seriedade intelectual e seu didatismo engajado e do afã por uma modernização (com a pretensa ideia de “progresso”) que sempre chegava atrasada e diluída, expressa numa estética “cafona”, entre outras.

[...] O tropicalismo surgiu assim, como moda; dando forma e sensibilidade moderna, debochada, crítica e aparentemente não empenhada. De um lado, associava-se a moda ao psicodelismo, mistura de comportamento hippie e música pop, indiciada pela síntese de som e cor; de outro, a uma revivescência de arcaísmos brasileiros, que se chamou cafonismo. Os tropicalistas não desdenharam este aspecto publicitário do movimento; sem preconceitos, interiorizaram-no em sua produção, estabelecendo assim uma forma específica de relacionamento com a indústria da canção. (FAVARETTO, 2000, p. 23)

Confundindo o nível em que se situavam as discussões culturais, o Tropicalismo "vendido como o mais novo produto cultural do mercado" (grifo nosso) ainda assim, politizou a arte e estetizou a política de forma não programática, promovendo rupturas nas formas de se fazer oposição não apenas à sociedade sob a égide de uma ditadura, mas também, numa perspectiva internacionalista, contra a sociedade "unidimensional" revelada por Marcuse (1982), regida pela tecnocracia e o capitalismo selvagem. Segundo Bueno (1979, p. 37), a incompreensão das propostas tropicalistas, não impediu suas manifestações de resistência perante o cerceamento da liberdade, que obteve visibilidade em shows improvisados, espetáculos teatrais, filmes super-8, publicações (que raramente chegavam a ter uma grande circulação e cuja existência era efêmera) e uma indumentária que "brincava" 
de forma oswaldiana, antropofágica, com os símbolos nacionais e estrangeiros, do presente e do passado e com os valores sacralizados da cultura ocidental. Torquato Neto esclarece: "Tropicalismo. O que é? Assumir completamente tudo o que a vida dos trópicos pode dar, sem preconceitos de ordem estética, sem cogitar de cafonice ou mau gosto, apenas vivendo a tropicalidade e o novo universo" (NETO APUD ROST, 2017, p. 74).

No decorrer da década de 1970, realizou-se uma série de experiências genericamente especificadas como "contraculturais", expressando aquilo que a poeta Ana Cristina César definiu como "comportamento desviante", originado a partir das experiências com o tropicalismo:

[...] A marginalidade é tomada não como saída alternativa, mas sim como ameaça ao sistema, como possibilidade de agressão e transgressão. A contestação é assumida conscientemente. O uso de tóxicos, a bissexualidade, o comportamento exótico são vividos e sentidos como gestos perigosos, ilegais e, portanto, assumidos como contestação de caráter político. (CESAR, 1993, p. 123)

A frustração, o medo e o desalento propiciado pelo contexto político geraram vozes dissonantes de resistência, artistas do underground brasileiro que ganharam visibilidade através da produção literária independente denominada genericamente de "underground, tropicalista, marginal, nanica, não alinhada, emergente e poesia jovem, entre outros vocábulos com suas múltiplas conotações e contradições, utilizados como sinônimos perfeitos de produção literária independente" (MICCOLIS APUD MELLO, 1986, p. 61). Entre as iniciativas dessa produção, ressaltamos a coluna mantida por Torquato Neto no jornal Última Hora, intitulada Geléia Geral ${ }^{5}$, porta-voz das experiências contraculturais brasileiras, veiculadas dentro

${ }^{5}$ Geléia Geral foi uma expressão criada por Décio Pignatari, em 1963, numa discussão com Cassiano Ricardo: (...) certa vez um bi-acadêmico poeta de vanguarda nos disse: o arco não pode permanecer tenso o tempo todo um dia tem que afrouxar \& um dia vocês têm de afrouxar \& nós: na geleia geral brasileira alguém tem de exercer as funções da "medula e do osso". Torquato Neto intitulou Geleia Geral sua famosa letra dos tempos da Tropicália e sua coluna no jornal carioca Última Hora. (DIAS, 2003, p. 51) 
da imprensa tradicional, constituindo-se em "medula e osso" da resistência através das palavras, especificamente, da poesia. O existencialismo de Torquato é visível em seus poemas, a exemplo do Hoje tem espetáculo:

\section{[...] e nas palavras todas}

na ferrugem dos gestos e nas trancas

da porta da rua

e frescura: montagem.

Divirta-se. O inferno

É perto é longe, o paraíso custa muito pouco.

Pra quem serve esse filme, serve a quem?

Pra que serve esse tema, serve a quem? (NETO, 1982, p. 25)

Torquato fez parte da geração tropicalista, compondo várias músicas com Caetano Veloso e Gilberto Gil. Quando o cerco da ditadura se fechou, na fase de sua volta ao Brasil nos anos 70, continuou escrevendo sobre o período sombrio; sua linguagem, a partir de então, demonstrava o que se chamava de "bode" contrapondo-se ao "barato" da fase anterior, tropicalista: Salvem-se quem puder!

[...] Informação: há palavras que estão nos dicionários e outras que não estão e outras que eu posso inventar, inverter. Todas juntas e à minha disposição, aparentemente limpas, estão imundas e transformaram-se, tanto tempo, num amontoado de ciladas. Uma palavra é mais de que uma palavra, além de uma cilada. Elas estão no mundo e, portanto, explodem, bombardeadas. Agora não se fala nada e tudo é transparente em cada forma; qualquer palavra é um gesto e em sua orla os pássaros de sempre cantam nos hospícios. No princípio era o Verbo e o apocalipse, aqui, será apenas uma espécie de caos no interior tenebroso da semântica. Salvem-se quem puder. As palavras inutilizadas são armas mortas e a linguagem de ontem impõe a ordem de hoje. (NETO, 1982, p. 23)

Em todos os poemas, colunas de jornal, notas de diário e fragmentos que compõem Os últimos dias de paupéria, organizado por Ana Maria S. de Coraújo Duarte e Waly Salomão, o inconformismo e o desespero são visíveis:

[...] Agora não se fala mais toda palavra guarda uma cilada e qualquer gesto é o fim do seu início; 


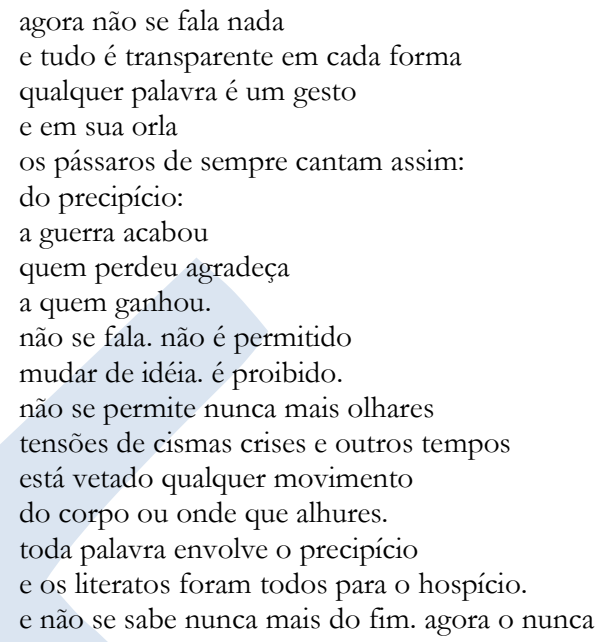

(NETO, 1973, p. 35)

Outro poeta de suma importância no entendimento da contracultura brasileira emergente e marginalizada é Waly Salomão com a obra Me segura que eu vou dar um troço (1972), escrita durante sua prisão no Carandiru. Com texto de caráter ambíguo, fragmentário e oscilante em vários aspectos, reverbera os impasses pessoais e as desagregações com a instância política, social e cultural da época. Segundo Bueno (1979, p. 91), o texto incorpora o retrocesso, a repressão e o fechamento vivido pelo Brasil pós 1968, além de um forte negativismo:

[...] Mortecimento precoce de nossas cidades mornas carvão cansado/ das nossas matas derruídas vomictório repleto de nossa/brasilidade senil ou melhor senilidade auriverde. (SALOMÃO,1972, p. 21)

[...] Estamos na ruína. Somos uns malditos para nossos irmãos e/para o povo da América. Horas Amargas estão reservadas/para o nosso país... (SALOMÃO, 1972, p. 37)

[...] Posso respirar dentro do cadáver do terceiro trópico/destes tristes mundos? (SALOMÃO, 1972, p. 14) 
O texto de Waly pregou o fim do sonho hippie, percebido em sua vertente brasileira, folclorizada e comercializada:

[...] Temos em comum, eu e os policiais, ódio asco aos hippies nacionais, à nossa campada horripielândia on the road. Viagens miseráveis, vapor barato. Um silone qualquer expõe desilusões descrenças e desgostos. Pronunciamento durante a cerimônia de auto e heterocrítica: abaixo a passividade repre-regressiva da horripielândia patrícia. (SALOMÃO, 1972, p. 21)

Waly Salomão organiza junto a Torquato Neto a revista Navilouca que foi publicada em 1974. Subintitulada Almanaque dos Aqualoucos teve propositalmente apenas uma edição, considerada uma produção sofisticada, diversa da precariedade e da improvisação características de outros alternativos.

[...] Queu não estou disposto a ficar exposto a cabecinhas ávidas quadradas

Ávidas em reduzir tudo todo esforço grandioso como se fosse expressão de ressentimentos por não se conformar aos padrões culturais:

Meu texto não é só prá ser visto numa ordem emocional (grilado ou sem bode, numa "boa", ou numa "ruim", incucado ou desbundado, alegre ou triste, amor ou ódio, etc.) porque os estados sentimentais são muito dependentes da rareté, da insuficiência carência de condições - deve ser vista do ponto de vista duma ordem menos impressiva, menos passiva, mais criadora - como experimentação de novas estruturas, novas formas de armação, como modo de composição não-naturalista. Alargamento não ficcional da escritura. (SALOMÃO, 1974)

O título Navilouca criado por Waly foi inspirado pela Stultiferas Navis, embarcação que recolhia loucos, idiotas e desgarrados nas costas da Europa na Idade Média, considerada comumente como o "período das trevas".

[...] A revista Navilouca transmutaria as imagens da loucura da época em manifestações artísticas, construindo um mosaico, composto de imagens, poesia, cinema e música, num caldeirão antropofágico, disposta a traduzir as peculiaridades culturais da contracultura, podendo ser percebida como enciclopédia da cultura subterrânea, por reunir os principais artistas e agitadores culturais da época, como Hélio Oiticica e Augusto de Campos, além daqueles artistas ainda 
não tão conhecidos, como o poeta Chacal, por exemplo. A proposta da revista seria "quebrar" com a normalidade (grifos da autora) estabelecida (durante a ditadura) assumindo o experimentalismo e privilegiando a imagem além do texto, onde inclusive o corpo poderia ser percebido como instrumento de revolução através do modo de viver e se comportar. (ROST, 2017, p. 241)

Neste cenário ainda ressaltamos a obra de Jorge Mautner, com influências da Beat Generation dos anos 50, percebidas na obra Deus da Chuva e da Morte (1958) e no lançamento do manifesto do "Kaos com K” (1985). Segundo Caetano Veloso (1997), tal manifesto simbolizava "a imaginação no poder", "o sexo na política”, "a religião além da irreligião", enfim, temas abordados pela contracultura.

Kaos é o anti cor-de-rosa

É Marx + Nietzsche

É a chegada do irracional

Num mundo economicamente satisfeito

No dia da fartura econômica

Virá sobre o mundo o grande delírio do sangue e do sexo

Surgirá de novo

Que nem na Grécia arcaica o ta-tã selvagem das canções de

E de outros deuses asiáticos

Dionísius-Exu

Não haverá deuses, o deus será o próprio homem que se [agoniará à

procura do grande mistério que restou: a morte.

[...] Kaos $=$ conflito criador. Kaos $=$ rebelião constante, postura trágica e dinâmica para a morte Heráclito e Heidegger, os maiores pensadores, que deram ao homem sua terrível dimensão (MAUTNER, 1985, p. 31-32).

Jorge Mautner embarcou na utópica "Era de Aquarius” colocando todo o seu lado pagão, sem culpas: “A minha carne é assim, vivo assim, compromete-se assim e neste despedaçamento atinge sua densidade porque está montada num cavalo metálico que se chama rock'n' roll” (MAUTNER APUD BUENO, 1979, p. 106). Acredita que após a revolução econômica, haveria a existencial, com a transcendência do homem, aberto a todas as possibilidades. 
[...] O coração do mundo. O coração em tudo. O amor, o romântico ululante e embriagado e dionisíaco dos sambas de Mirabeau, do Jorge Ben, dos Rolling Stones, nosso espaço cultural fragmentado é o caminho da liberdade. E a liberdade como lembra Norman Brown lembrando Shakespeare é como Cordélia, vem com as mãos vazias, vem trazendo o nada. E o nada são todas as possibilidades... (MAUTNER, 1985, p. 37).

Essas foram algumas das iniciativas que ganharam visibilidade na literatura e que formularam, a partir de uma profícua teia de referências nacionais e estrangeiras, a formação da contracultura no Brasil. Foi dentro desse contexto que surgiu a obra Pan América de José Agrippino de Paula que "deglute", tal como dita a antropofagia oswaldiana, diversas referências do contexto vivido na década de 60 com uma linguagem insólita, seguindo um dos objetivos principais daquela geração "que era o de criar uma arte que fosse não apenas genuinamente brasileira e socialmente comprometida - como suas antecessoras imediatas -, mas também avançada, mesmo em relação ao que se fazia nos países do Primeiro Mundo” (MACIEL, 2014, p. 144).

\section{A “ viagem antroPOPfágica” de José Agrippino de Paula na obra Pan América}

[...] Eu sobrevoava com o meu helicóptero os caminhões despejando areia no limite do imenso mar de gelatina verde. Sobrevoei a praia que estava sendo construída e o helicóptero passou sobre o caminhão de gasolina onde um negro experimentava o lança-chamas. Eu falei com o piloto do meu helicóptero apontando o caminhão de gasolina, e o helicóptero fez uma manobra sobre o caminhão-tanque e pousou alguns metros adiante. Eu saltei do helicóptero e gritei para o enorme negro que verificava o lança-chamas: "Hei!" Eu perguntei a ele como estava o lança-chamas para funcionar como coluna de fogo. O preto disse que eu me afastasse alguns metros e ligou o lança-chamas para o alto. O lança-chamas esguichou para cima um jato de fogo e o enorme negro fazia sinais para o homem que controlava a gasolina junto ao carro-tanque. Eu gritei para o negro que estava ótimo, que era exatamente aquilo que eu desejava. O negro foi controlando a saída de gasolina e a enorme nuvem de fogo erguida para cima foi diminuindo até se extinguir. Eu perguntei ao negro se ele sabia onde ele ia se esconder com o lança-chamas. O negro respondeu que o engenheiro já havia cons- 
truído uma pequena elevação no mar de gelatina verde, e o esconderijo já estava cuidadosamente construído. "E o Burt?", perguntei. O preto disse que não sabia, quando eu vi surgir do fundo de um edifício um caminhão trazendo Burt Lancaster com duas enormes asas brancas sobre os ombros. $\mathrm{O}$ caminhão estacou e eu perguntei: "Tudo bem, Burt?" "Péssimo!...", respondeu Burt de cima do caminhão, com seus trajes brancos e as duas asas de anjo para cima (Pan América, 1967).

José Agrippino de Paula, um dos mentores do Movimento Tropicalista, nasceu na cidade de São Paulo, arquiteto de formação se realizou, no entanto, na área artística. Lançou obras literárias tidas por artistas e pesquisadores, como singulares, vanguardistas, enveredando-se também no cinema, teatro e música. A obra Lugar Público, seu romance de estreia, foi publicado em 1965 pela editora Civilização Brasileira, retratando a urbanidade, a solidão na metrópole, a vida sem sentido e mecânica expressa em personagens com nomes de figuras que se destacaram historicamente como Napoleão, César ou Pio XII, mas que na narrativa estão à deriva, impotentes executando apenas as ações cotidianas:

Eu abro a porta do quarto, entro na sala, abro a porta da sala e entro no elevador. O elevador desce, eu abro a porta, percorro um corredor, desço três degraus, e saio para a rua. Os automóveis e ônibus passam nos dois sentidos, e de um e de outro lado da rua existem automóveis e caminhões estacionados. Os dois pares de fios do ônibus elétrico acompanham o sentido da rua. A rua é estreita e cercada por prédios de doze andares; dois ou três prédios em construção interrompem a regularidade da altura. [...] Entro no túnel. O túnel serve de continuação para a avenida e penetra no morro de pedra. Profundidade: por volta de quatrocentos metros. O teto do túnel é curvo e ladrilhado por ladrilhos brancos cobertos por uma camada escura de fuligem. Os carros passam velozes e o som produzido pelos motores e pelas buzinas é multiplicado: o som ressoa nas paredes de pedra. (PAULA, 1965, p. 182-183)

Tal obra caracterizou uma ruptura estética frente às formas de se fazer literatura no Brasil levando a sua radicalização em Pan América que foi seu segundo livro, publicado em 1967 pela editora Tridente e que teve mais duas edições; em 1988, pela extinta editora Max Limonad e pela editora paulistana Papagaio, em 2001. Apresentada pelo autor como epopeia, ou seja, uma narrativa extensa sobre feitos memoráveis, heroicos foi apresentada em sua 
primeira edição pelo crítico e físico Mário Schenberg como "uma contribuição de importância internacional para a utilização literária de alguns dos mitos fundamentais contemporâneos" (PAULA, 1967). Em sua primeira edição é colocada uma nota explicativa do conteúdo:

Qualquer semelhança existente entre personagens da presente epopeia não é pura coincidência. Todavia, essas personagens aparecem no texto do autor como símbolos motivadores do mito, sem relação existencial com seu verdadeiro valor humano ou com sua vivência espiritual e carnal. (PAULA, 1967, p. 7)

Tal obra foi além dos ditames normalizadores, representando uma nova subjetividade polifônica, fragmentada, lisérgica, inerente à contracultura: “Os bilhões de espermatozoides formaram um redemoinho negro sobre o lago artificial da feira, e giravam zumbindo a uma velocidade supersônica" (PAULA, 1967, p. 186).

O aspecto surrealista do texto é apresentado através da sucessão de imagens bizarras que parecem advindas do inconsciente através de uma experiência lisérgica, forma de descondicionamento dos jovens então imersos na contracultura. Sua linguagem espontânea estabelece interseção com a literatura beat e com a linguagem cinematográfica "não apenas como tema ou fornecedor de mitos e de elementos para a composição da obra, mas como princípio de composição e organização da própria escrita” (ARRUDA, 2016, p. 89). Ao primeiro olhar do leitor, o texto apresenta um caráter ininteligível que esconde uma "epopeia pop antropofágica" (grifo nosso) que se torna evidente à medida que o livro é lido, em sintonia com o cotidiano dos centros urbanos, sob o viés da industrialização, do consumismo e da comunicação de massa. A despretensão e o espontaneísmo das frases e dos capítulos que ignora o recurso de abrir novos parágrafos, conduz o leitor a uma imersão lírica num on the road pela América desterritorializada.

[...] O texto é composto por blocos de palavras, sem parágrafos, em seções que podem ser compreendidas como capítulos. Não existem

${ }^{6}$ Apresentação de Mário Schenberg para a primeira edição da referida obra. 
divisões formais. É o testemunho de um narrador multifacetado, mutante, que conta, em primeira pessoa, sua errância por vários mundos. Começa apresentando-se como um diretor de cinema em Hollywood, filmando a superprodução A Bíblia, com diversos ataques de megalomania. Alguns capítulos depois, está transitando por países da América Latina, sem respeitar fronteiras, como membro de um exército guerrilheiro. No final, assiste a destruição do planeta, que se transforma em estilhaços vagando pelo espaço. No meio de tudo isto, ícones originários dos mais diversos meios, como históricos, religiosos e, principalmente, do cinema hollywoodiano, inflam a narrativa. (BENTO, 2008, p. 146)

De Hollywood como diretor de cinema a um guerrilheiro na América Latina, a epopeia alcança diversos países, caracterizados de forma vaga a fim de se ressaltar a ideia de uma grande pátria latino-americana (BENTO, 2008):

[...] Em Panamérica, a preocupação de se pensar o continente como um bloco único encontra ressonância na parte intermediária da narrativa, quando o narrador tem sua identidade deslocada de diretor de cinema em Hollywood para guerrilheiro na América Latina. Então, ele se desloca por diversos países, sem qualquer problema com fronteiras. Os locais por onde passa são apenas sugeridos por características mais ou menos precisas. Por exemplo, em uma parte em que o narrador diz estar em cima de uma montanha, onde há a imagem de um Cristo de braços abertos. A descrição remete, em uma primeira leitura, ao pensamento de que se trata do Cristo Redentor, no Rio de Janeiro. A reflexão, no entanto, mostra que a figura do Cristo encontra-se em muitas cidades brasileiras. Porém, se pensarmos em um clichê para ser exibido aos turistas estrangeiros, que pensam no Brasil metonimicamente representado apenas pelo Rio de Janeiro, a imagem remeteria inevitavelmente à conclusão de que se trata da capital carioca. Fato é que as características descritas no livro apenas sugerem o país em que o narrador guerrilheiro se encontra, estratégia que corrobora a intenção de representar a grande pátria latino-americana, em vez do Brasil. (BENTO, 2008, p. 149)

Além da imersão na América, a obra expressa questões comportamentais que ganharam visibilidade com a contracultura, a exemplo da questão do corpo, da sexualidade, presente em alguns trechos denotando não uma problematização do tema, mas uma transcendência do mesmo, vivido intensamente de forma libertária na narrativa: 
[...] Eu tocava o corpo dela de leve com meu corpo e ela tocava de leve o meu corpo com o corpo dela. Nós permanecemos nessa oscilação e toques leves durante longo tempo. Marilyn Monroe tocava a pontas dos seios no meu peito e eu segurava de leve a sua barriga e acariciava os pelos dela com os dedos. (...) Nós permanecemos nesse toque mútuo longo tempo [sic] enquanto eu ouvia a sua respiração leve e ritmada. (PAULA, 2001, p. 63-64)

[...] Eu me aproximei da cama onde estava o adolescente deitado de calção e beijei o seu pescoço. Eu estava excitado e sentia o corpo do soldado adolescente e a sua voz grave e baixa. O soldado sorriu e olhou o teto. Eu falei baixo que ele era lindo e o adolescente sorriu novamente. Eu segurei o calção do adolescente e puxei o calção para baixo. Eu abri as nádegas do soldado nu e, deitado numa das camas do alojamento, eu esfregava o meu membro rijo entre as suas nádegas. (PAULA, 2001, p. 90)

Através de Pan América vislumbra-se a história de uma época, na apropriação de símbolos culturais e políticos sem a finalidade propriamente de se fazer uma revolução política, antagonizando o didatismo da arte engajada do Brasil nos anos 1960. Pan América é a própria revolução em forma e conteúdo, o meio e a mensagem de um país subdesenvolvido. Arruda (2016) afirma que:

Mesmo que o tempo histórico não seja mencionado na narrativa, que ele não seja contextualizado, já que os acontecimentos inseridos na esfera mítica não têm qualquer referência temporal, não é difícil entendermos o romance como um produto de um mundo polarizado e altamente tecnológico. Mais especificamente ainda como produto de uma realidade subdesenvolvida. Assim, não seria irônico, portanto, chamarmos Pan América de um romance subdesenvolvido. (ARRUDA, 2016, p. 95)

A literatura fantástica, a história da América, o surrealismo, a literatura beat, o dadaísmo, a estética $p \circ p$, a antropofagia oswaldiana como mote, entre outras miríades de possibilidades, caracterizaram a intensidade e a crítica de José Agrippino de Paula mediante ao sistema instituído, desterritorializando-se na arte e assim, como sugeria sempre, fazendo o seu "barulho". 


\section{Considerações Finais}

Pan América tem implicações políticas internacionais, e eu, que me considero tão brasileiro como vietnamita, venezuelano ou egípcio, as considero tanto de universo quanto do Brasil. Lugar Público é um livro auto-biográfico da arte da forma. Pan América é criação do meu mundo com todas as suas peças, objetos, personagens e situações. O primeiro livro foi montado e escrito em grande parte depois da fossa de 64. A estagnação social e individual é o tema. Mas hoje, apesar da prisão de ventre nacional, em outras partes do mundo se vê heroísmo, fé e violência. O épico narra grandes acontecimentos, onde participam deuses e homens. Meu livro tem fé no mundo. (PAULA APUD FARIAS, 2016, p. 72) ${ }^{7}$

O presente trabalho teve como objetivo geral apresentar os significados dentro de uma perspectiva histórica, da obra Pan América de José Agrippino de Paula, com seus elementos oriundos de um realismo fantástico, ao mesmo tempo, como uma alegoria verossímel dos anos 1960. Ressaltamos em um primeiro momento, o contexto histórico no qual se deram algumas iniciativas caracterizadas como contraculturais em momento de cerceamento da liberdade advindos do regime militar. Apresentamos poetas e obras contemporâneas as de José Agrippino de Paula que dialogaram entre si e que delinearam formas diferenciadas de resistência e contestação ao momento vivido. A essa produção de artistas em fins dos anos 1960 e início dos anos 1970, chamamos de produção independente, expressas através de centenas de impressos alternativos, revistas, jornais e livros comunicando uma contrainformação a oficial, coadunada com os movimentos contraculturais que eclodiam em todo mundo, ganhando nuanças específicas em cada lugar onde se estabeleciam. No Brasil, o Movimento Tropicalista inicialmente catalisou as inquietações de parte da juventude envolvida com as diferentes formas de resistência ganhando uma conotação essencialmente artística. Segundo Veloso (1997) a obra Pan América foi de suma importância para a elaboração do Tropicalismo, considerada um marco dentro das produções literárias

${ }^{7}$ Entrevista a Carlos Freire, jornalista da Tribuna de Imprensa, realizada em 21 de julho de 1967 (FARIAS, 2016, p. 72). 
da época, notadamente contracultural em sua forma e conteúdo, dialogando numa perspectiva oswaldiana, com influências estrangeiras e nacionais, do presente e do passado, num caldeamento híbrido que resultou numa inovação e construção através da experimentalidade de novas linguagens.

Além de seus livros, o escritor fez incursões no cinema, com filmes como Hitter do Terceiro Mundo (1968) e também no teatro, montando, junto com a esposa, a bailarina Maria Esther Stokler, trechos do roteiro teatral Nações Unidas, publicado em inglês, originalmente em 1968 com o título de United Nations em edição mimeografada e ainda inédito em livro (ARRUDA, 2016). Também produziu shows para o grupo Os Mutantes e depois se deixou levar pela onda hippie on the road, passando pela África, Estados Unidos e a Bahia, vivendo em comunidades alternativas. Em 1980, recebeu diagnóstico de esquizofrenia e desde então passou a viver em Embu das Artes, cidade do interior de São Paulo, em condições precárias, falecendo em 2007. A dimensão de suas produções artísticas alcança o século XXI ainda como transgressoras e vanguardistas.

\title{
"TROPICALIST PANAMERICS" THROUGH THE LITERATURE CONTRACULTURAL OF JOSÉ AGRIPPINO DE PAULA
}

\begin{abstract}
The aim of this article is to discuss Pan America (1967) by José Agrippino de Paula e Silva (1937-2007), published in the context of the Military Dictatorship of 1964, modulated by Tropicalism, considered by many researchers as the face of the counterculture in Brazil. In order to deal with this theme, we will focus on the historical context in which the work Pan America was produced and, later on, the fiction, the unusual, the fantastic realism and other components of the work that provided a rupture to the literary standards both in form and content, making it marginal at the time and reaching the 21 st century still as an innovator and founder of a new aesthetic sensibility.
\end{abstract}

KEYWORDS: Counterculture; Tropicalismo; Military Dictatorship of 64; José Agrippino de Paula; Brazilian literature.

\section{REFERÊNCIAS}

ARRUDA, Vinícius Galera de. Fora do lugar - a ficção de José Agrippino de Paula. 2016. 143f. Dissertação de Mestrado - Faculdade de Letras Clássicas e Vernáculas. Área de concentração: Literatura Brasileira. São Paulo, 2016. 
BENTO, C. H. Pan e latina-América: o delírio épico de José Agrippino de Paula. Ipotesl, Juiz de Fora, no. 1, p. 145-153, jan./jun. 2008.

BRITTO, Paulo Henriques. "A temática noturna no rock pós-tropicalista”. In: NAVES, Santuza Cambraia; DUARTE, Paulo Sérgio (orgs.). Do samba-canção à tropicália. Rio de Janeiro, FAPERJ/ Relume Dumará, p. 191-199, 2003.

BUENO, André Luiz de Lima. Contracultura: as utopias em marcha. Rio de Janeiro, 1979. 200f. Dissertação (Mestrado em Letras). Pontifícia Universidade Católica do Rio de Janeiro, 1979.

CAPELLARI, M. A. O discurso da contracultura no Brasil: o Underground através de Luiz Carlos Maciel. 2007. 256p. Tese (Doutorado em História Social). Universidade de São Paulo, São Paulo, 2007.

CÉSAR, Ana Cristina. Escritos no Rio. Rio de Janeiro; São Paulo: UFRJ; Brasiliense, 1993.

CONTIER, A. D. et al. O Movimento Tropicalista e a revolução estética. Caderno de PósGraduação em Educação, Arte e História da Cultura. São Paulo: Editora Mackenzie, v. 3, n.1, 2003, p. 135-159.

CYNTRÃO, S. H. A forma da festa. Tropicalismo: a explosão e seus estilhaços. Brasília: Editora da UNB, 2000.

DIAS, Lucy. Anos 70: enquanto corria a barca. São Paulo: Editora Senac, 2003.

DUNN, C. Brutalidade jardim: a Tropicália e o surgimento da contracultura brasileira. São Paulo: Editora UNESP, 2009.

FAVARETTO, C. Tropicália, alegoria, alegria. 3. ed., São Paulo: Ateliê Editorial, 2000.

FARIA, Bernardo de Paola Bortolotti. Literatura enquanto contracultura: José Agrippino de Paula, malabarista de sonhos e possibilidades. 2016. 105 f. Dissertação de Mestrado Pontifícia Universidade Católica do Rio de Janeiro, Departamento de Letras, 2016.

GARCIA, Marco Aurélio e VIEIRA, Maria Alice. Rebeldes e contestadores: 1968, Brasil, França e Alemanha. São Paulo: Perseu Abramo, 1999.

GOFFMAN, K.jJOY, D. A contracultura através dos tempos: do mito de Prometeu a cultura digital. Trad. Alexandre Martins. Rio de Janeiro: Ediouro, 2007.

GONÇALVES, Daniel José. O desbunde como manifestação politica: a identidade de gênero na obra de Ana Cristina César. Curitiba, 2008. 126p. Dissertação (Mestrado em Estudos Literários). Universidade Federal do Paraná, Curitiba, 2008.

HOLLANDA, Heloísa B. e GONÇALVES, Marcos A. Cultura e participação nos anos 60. 3. ed., São Paulo: Brasiliense, 1984. 
MACIEL, Luiz Carlos. Anos 60. Porto Alegre: L\&PM, 1987.

. O sol da liberdade. Rio de Janeiro: Vieira \& Lent, 2014.

MARCUSE, H. A ideologia da sociedade industrial: o homem unidimensional. Tradução de Giasone Rebuá. Rio de Janeiro: Zahar, 1982.

MAUTNER, Jorge. Deus da chuva e da morte. Rio de Janeiro: Azougue Editorial, 1962. Fundamento do Kaos. São Paulo: Ched Editorial, 1985.

MELLO, Maria Amélia (organização). Vinte anos de resistência: Alternativas da Cultura no Regime Militar. Rio de Janeiro: Espaço e Tempo, 1986.

NETO, Torquato. Os últimos dias de Paupéria. 2. ed. São Paulo: Max Limonad, 1982.

PAULA, José Agrippino de. PanAmérica. 1. ed., São Paulo: Tridente, 1967. . PanAmérica. 3. ed., São Paulo: Papagaio, 2001. . Lugar Público. Rio de Janeiro: Civilização Brasileira, 1965. . Lugar Público. São Paulo: Papagaio, 2004.

ROST, Isis. O risco do berro: Torquato, Neto Morte e Loucura. São Luís: edição da autora, 2017.

ROSZAK, Theodore. A Contracultura. São Paulo: Vozes, 1972.

SALOMÃO, Wally. Me segura que eu vou dar um troço. São Paulo: José Álvaro Editora: 1972 . Plantamiento de custiones. Navilouca. Rio de Janeiro: Gernasa, 1974.

VELOSO, Caetano. Verdade Tropical. São Paulo: Cia das Letras, 1997.

VENTURA, Zuenir. 1968: o ano que não terminou. Rio de Janeiro: Nova Fronteira, 1988.

Recebido em: 14/04/2019.

Aprovado em: 19/6/2019. 